\title{
A Randomised Pilot Study on the Efficacy of Milking Cream and a Homeopathic Complex Topical Cream on Diaper Dermatitis
}

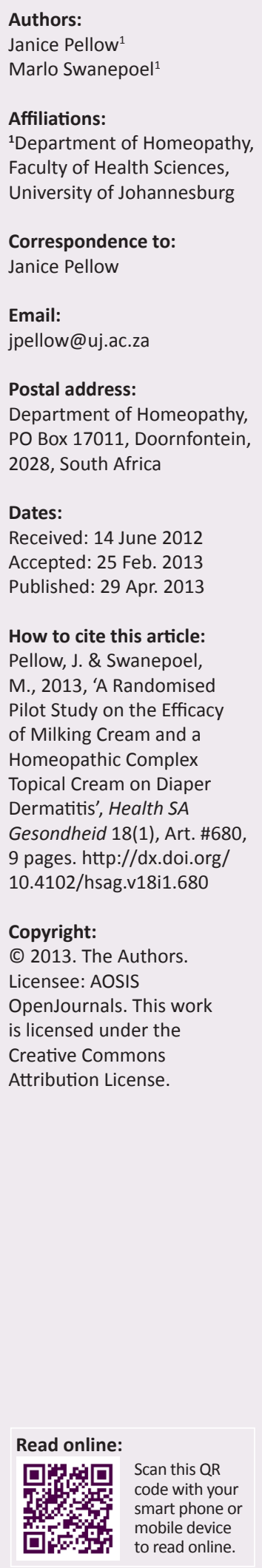

Diaper dermatitis (DD) is an acute inflammation of the skin in the diaper area and is the most common cutaneous disease among infants and children. Calendula officinalis, Atropa belladonna and Sulphuricum acidum are homeopathic remedies which have been purported to be beneficial in wound healing and conditions affecting the skin, however, to date, no research has been conducted on the use of these remedies for DD. The aim of this seven-day, double-blind, controlled pilot study was to assess the efficacy of milking cream and a homeopathic complex cream as topical treatments for DD. Forty children between the ages of three to 24 months with DD were recruited. The homeopathic complex cream $(n=20)$ or unmedicated milking cream $(n=20)$ was applied after every nappy change for seven days. Efficacy on the severity of symptoms and the percentage of area affected was assessed by means of the 4-Point Grading Scale and the Modified Lund and Browder Charts respectively, on days 1, 2, 4 and 7. The results revealed that both groups showed statistically-significant improvements on rash severity and the percentage of area affected between consecutive visits, as well as over the entire research study period. Trends indicated that the treatment group had a faster resolution of symptoms and outperformed the control in certain affected body regions. Preliminary findings suggest that both milking cream and the homeopathic complex cream may be effective alternative treatment options for DD, and further investigation is warranted.

Luier dermatitis (LD) is ' $n$ akute inflammasie van die vel in die luier area en is die algemeenste velsiekte onder babas en kleuters. Calendula officinalis, Atropa belladonna en Sulphuricum acidum is beweerde homeopatiese middels wat voordelig is in wondgenesing en ander velkondisies. Tot ophede is daar geen navorsing gedoen op die doeltreffendheid van die bogenoemde middels op LD nie. Die doelwit van die sewe dag, dubbele-blinde, beheerde-loodsstudie was om die doelteffendheid van melksalf en ' $n$ homeopatiese mengsel te evalueer as topikale behandelinge vir LD. Veertig babas tussen die ouderdomme van drie maande tot 24 maande was gewerf om deel te neem aan die studie. Die homeopatiese mengsel room $(n=20)$ of die melksalf $(n=20)$ was aangewend met elke luier vervanging vir sewe dae lank. Die doeltreffendheid van die room was beoordeel op dag 1, 2, 4 en 7 aan die erns van die simptome en die persentasie gebied wat geraak was, met behulp van 'n 4-Punt Graderingsskaal en die Gewysigde Lund en Browder Grafiek onderskeidelik. Uitslae het getoon dat die behandelingsgroep en die kontrolegroep albei statistiese, beduidende verbeteringe getoon het op die erns van die uitslag en die persentasie gebied wat geraak is, tussen opeenvolgende besoeke sowel as die hele studie tydperk. Tendense dui daarop dat die behandelingsgroep ' $n$ vinniger oplossing van simptome getoon het en beter gevaar het as die kontrolegroep in sekere geaffekteerde liggaamstreke. Voorlopige bevindinge dui daarop dat beide melksalf en die homeopatiese mengsel room effektiewe, alternatiewe behandelings opsies vir LD is en dat verdere ondersoek geregverdig is.

\section{Introduction}

\section{Problem statement}

\section{Background}

Diaper dermatitis (DD) is an acute inflammation of the skin in the perineal area and is the most common cutaneous disease amongst infants and children (Fölster-Holst, Buchner \& Proksch 2011). The exact prevalence is not known as many cases are self-medicated by parents or guardians (Wolf et al. 2000), however it is estimated that between $7 \%$ and $35 \%$ of diaper-wearing infants are affected during the period of wearing diapers (Barkin \& Rosen 2003:588-589).

DD is a type of irritant contact eczema characterised by erythema, inflammation, itching and pain, as well as papulovesicular or pustular eruptions of the skin in the diaper area. In severe cases, ulceration may occur (Visscher \& Hoath 2006). The most distinctive feature of DD is that there 
is sparing of the skin folds (Friedlander et al. 2009). One of the biggest complications of DD is secondary infections with either anaerobic bacteria such as Staphylococcus spp. or Streptococcus spp., or fungi such as Candida albicans (Fernandes, Machadoll \& De Oliveirall 2009). Research shows that as many as $77 \%$ of patients presenting with DD may become infected with $C$. albicans (Concannon et al. 2001).

DD is primarily caused by the environment present within the diaper. Although diaper technology has improved in recent years, resulting in a decrease in both incidence and severity of $\mathrm{DD}$, this condition remains a common problem (Fernandes et al. 2009). The following factors all compromise the barrier function of the stratum corneum, making the skin more susceptible to DD: ammonia levels, friction, levels of skin hydration (influenced by the type of diaper), $\mathrm{pH}$ level, proteolytic and lipolytic enzymes contained in the urine and faeces, micro-organisms present, diet (which has an effect on the alkaline levels), and skin maturation (De Wet et al. 1999; Fölster-Holst et al. 2011).

DD tends to be episodic and is relatively self-limiting, unless secondary infections occur (Friedlander et al. 2009). Management of this condition involves frequent diaper changes and cleaning of the area with water and a $\mathrm{pH}$ balanced mild soap (Fernandes et al. 2009). Commerciallyavailable moisture barrier creams usually contain one or more of the following ingredients: petrolatum, mineral oil, dimethicone, zinc oxide, and lanolin; and have been shown to decrease trans-epidermal water loss and to improve skin conditions in some patients (Visscher 2009). These creams may result in allergic reactions in hypersensitive patients, and are usually ineffective for severe cases of DD (Friedlander et al. 2009; Visscher 2009). Corticosteroids are prescribed for persistent DD to reduce inflammation. Adverse effects such as skin atrophy and adrenal axis suppression are possible even with low doses, due to the relatively large body surface area covered, as well as the occlusive effect of the diaper (Friedlander et al. 2009; Railan et al. 2002:3). Topical antifungal creams or antibiotics are usually prescribed to treat secondary infections and are usually well tolerated (Friedlander et al. 2009; Wahrman \& Honig 2000:58). These drugs may, however, result in various adverse effects when prescribed for systemic use (Snyman 2007).

\section{Aim of the study}

This pilot study aimed to assess the efficacy of milking cream and a homeopathic complex cream as topical treatments for Diaper dermatitis.

\section{Trends}

A homeopathic complex is a combination of remedies prescribed together based on their indication for a particular disease condition (Kayne 1997:163; Vithoulkas 1981:15). In this study, three remedies were chosen that are indicated clinically for the symptoms of DD, namely, Atropa belladonna $6 \mathrm{cH}$, Calendula officinalis D1, and Sulphuricum acidum $6 \mathrm{cH}$. A. belladonna is indicated for dry, hot, burning, bright red, inflamed skin (Vermeulen 2001:161-168). Studies done on the use of $A$. belladonna extract on skin wounds in rats have showed a positive effect of increasing the rate of aseptic surgical wound healing. Higher dilutions appeared to have a more therapeutic effect, whereas lower dilutions appeared to increase cell death (Gál et al. 2009, 2012; Toporcer et al. 2006). In this study, A. belladonna was used in a $6 \mathrm{cH}$ potency to ensure safety.

Calendula officinalis is indicated for skin conditions where there is inflammation, erythema, suppuration and pain (Vermeulen 2001:230-231), and has been shown to have anti-inflammatory, antiviral, antibacterial and antifungal properties (Muley, Khadabadi \& Banarase 2009). One recent study found Calendula ointment to be a safe and effective treatment for DD in infants (Panahi et al. 2012).

Sulphuricum acidum $6 \mathrm{cH}$ is indicated for skin conditions where there are livid, red, itchy blotches (Vermeulen 2001:930-933) such as are found in DD.

Milking cream was chosen as the control cream, as well as the vehicle for the homeopathic complex, as it contains chlorhexidine (an antiseptic), Vitamin E (which has antiinflammatory activity and maintains cell membrane structure) and lanolin (which has emollient effects and increases wound healing rates) (Stone 2000; Thiele \& EkanayakeMudiyanselage 2007; Visscher 2009; Wohlrab, Jost \& Abeck 2007). Although no studies have been conducted on its use for DD, milking cream remains a potentially-effective alternative to other brand-name barrier creams, as it is cost effective and its ingredients have similar antiseptic and emollient properties.

\section{Research aim}

The remedies used in this study have been widely used by homeopaths for the treatment of inflamed and painful skin conditions such as DD, however to date there have been no studies evaluating the efficacy of this homeopathic complex in the treatment of infants with DD. The primary objective of this pilot study was to evaluate the efficacy of both the milking cream and the homeopathically-medicated milking cream in the alleviation of DD symptoms, and the secondary objective was to compare the effects of these two creams.

\section{Contribution to the field}

This study has contributed to our knowledge on the use of milking cream as well as the homeopathic complex cream for $\mathrm{DD}$, opening up the field for further studies to be conducted. This research highlights the potential therapeutic benefits of these creams in the management of infants with DD and its complications, and this information is of great value to health practitioners, caregivers and parents.

\section{Research method and design Design}

This was a seven day, randomised, double-blind, controlled pilot study involving forty participants from the ages of 3 to 24 months, placed in matched pairs. The hypothesis was that 
the homeopathic medication added to a milking cream base would alleviate the signs and symptoms of DD more rapidly than the group that only received milking cream.

\section{Data collection methods}

The study was conducted at the Homeopathic Health Training Centre, at the Doornfontein campus of the University of Johannesburg (UJ). Participants were recruited by means of purposive sampling via word of mouth, and by means of advertisements placed at UJ, at nursery schools and at hospitals in the area, with relevant permission given. Participants with $\mathrm{DD}$, between the ages of 3 months to 24 months, who were wearing disposable diapers on a daily basis, were recruited into the study. Participants not using diapers continuously; with any other known dermatological disease; with an allergy or sensitivity to disposable diapers or skin care products; using any chronic or ongoing medications that might have affected the outcome of the study; or with a known allergy to any of the ingredients in the treatment or control creams were excluded from the study. Severe cases involving ulceration of the skin, or those showing no improvement within a few days, were referred to their relevant health care provider. Participation in this study was voluntary. The participants' parents or guardians were required to sign the information and consent form, which explained in detail the purpose of the study and all procedures related to it.

The participants' parents or guardians completed the Parent/ Guardian Questionnaire (modified from Palestine et al. n.d.) specific to this study before treatment started. Participants were allocated to either Group A $(n=20)$ or Group B $(n=20)$ using matched pairs according to severity in order to ensure equal distribution in both groups. The researcher then completed a case history and an evaluation of the rash according to a 4-Point Grading Scale (Concannon et al. 2001; Visscher \& Hoath 2006) in order to determine the severity at 10 sites. The percentage of area affected was determined by using the Modified Lund and Browder Chart (National Registry of Emergency Medical Technicians n.d.). One group received a $200 \mathrm{~g}$ tub of milking cream containing Atropa belladonna $6 \mathrm{cH} \mathrm{3 \% ,} \mathrm{Sulphuricum} \mathrm{acidum} 6 \mathrm{cH} \mathrm{3 \%}$ and Calendula officinalis D1 3\%, and the other group received a $200 \mathrm{~g}$ tub of unmedicated milking cream. The researcher demonstrated the application of the cream in the presence of the participants' parents or guardians at the end of the initial consultation. The parents or guardians were requested to apply the cream to the affected area during the normal diaper changing routine as well as after every bath. They were asked to continue their normal diaper changing routine and not to change the child's diet, wet-wipe brand or nappy brand for the duration of the study. If any other cream or intervention was used, they had to notify the researcher. The parents or guardians were asked to keep a record of every application in the progress diary provided and to note any adverse effects from the use of the cream. The follow-up visits took place on days 2, 4 and 7 and involved a re-evaluation of all 10 areas by the researcher. Every effort was made to ensure consistency between participants, and all consultations were performed in the same consultation room under similar lighting conditions.

\section{Validity and reliability}

The 4-Point Grading Scale evaluated the severity of DD, and was modified from a similar grading scale used effectively in previous dermatological studies (Visscher \& Hoath 2006). This evaluation looked at ulceration, scaling, rash papules, rash, oedema, redness, macules and continuous redness in all 10 areas, adding to a total score of 40 . The higher the rating, the more severe the rash. The total percentage area affected was determined by the use of the Modified Lund and Browder Chart, looking at the same 10 areas as mentioned above, and referred to as the total nappy area. This chart is based on the Lund and Browder Chart, which is used for assessing burn wounds on the skin (National Registry of Emergency Medical Technicians n.d.). Wachtel et al. (2000) recommend the Lund and Browder Chart as being one of the most effective tools to use for determining body percentage, as it acknowledges age-related body ratio differences. The body is divided into various areas, with associated percentages assigned to each part, according to the ratio it occupies in comparison to the body.

\section{Data analysis}

All pertinent data collected was analysed by STATKON (the statistical department of UJ) using the following tests: within group analysis via the Friedman test and Wilcoxon signed ranks test; between group analysis via the MannWhitney Test. A $p$-value less than 0.05 was considered to be statistically significant, except for the Wilcoxon signed ranks test, where the Bonferroni adjustment was applied, meaning that for a statistically-significant difference the $p$-value must be less than 0.0083 (J. van Staden [pers. comm.]).

\section{Ethical considerations}

Research was approved by the University of Johannesburg's Faculty of Health Sciences Higher Degrees Committee (HDC75/2-2-10) and Academic Ethics Committee (AEC76/012010). There were no anticipated risks to the study. Participants with severe DD or with a suspected hypersensitivity reaction to any of the ingredients in the creams were referred to their healthcare provider. Participants were ensured of privacy and all consultations took place in private consultation rooms. Anonymity was maintained by participants being allocated a number by the researcher and all files were kept under lock and key, thus ensuring confidentiality.

\section{Results}

Forty-five participants were recruited for the study. Five participants were excluded as they were suffering from other diagnosed skin conditions. The remaining participants were matched according to severity of the DD into two groups of 20 participants each. One participant from the treatment group and two from the control group withdrew from the study (see Figure 1), thus 37 participants completed the 


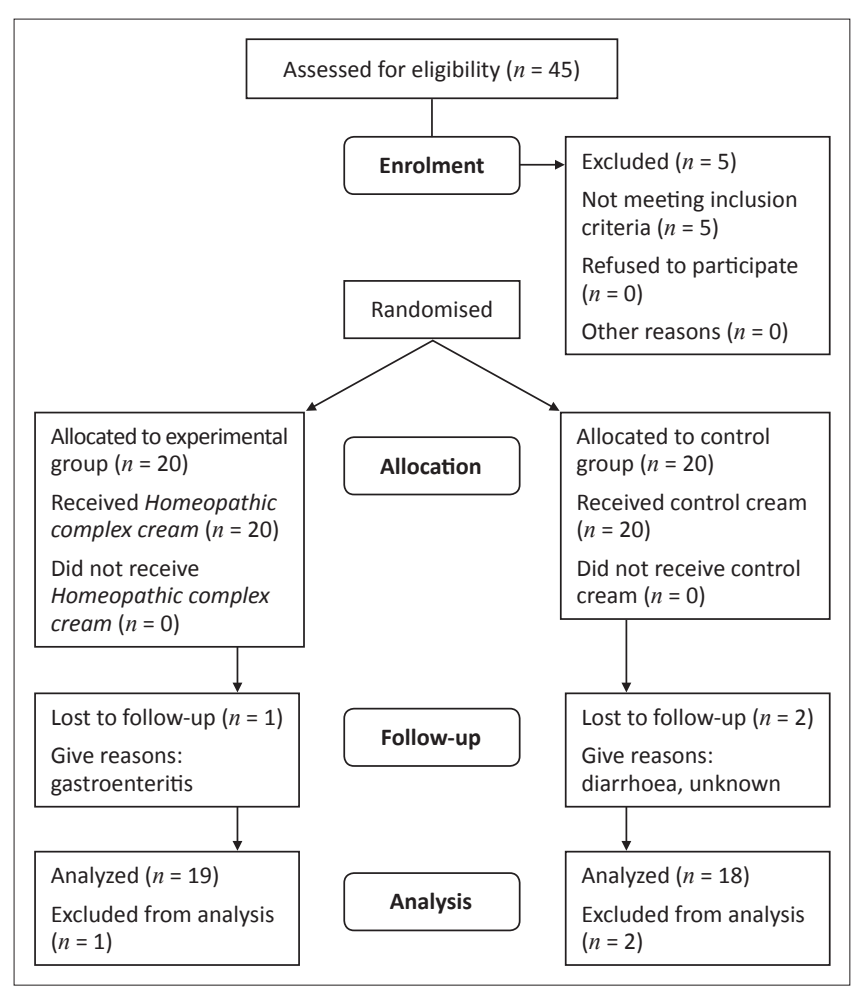

Source: Schematic developed for study

FIGURE 1: The Consort E-Flowchart.

study. The gender and age distribution was similar between the two groups (treatment group: females 65\%; average age 5.8 months; control group: females $70 \%$; average age 6.3 months. For analysis purposes each of the 10 body area's measurements (Modified Lund and Browder Chart and 4-Point Grading Scale) were compared on the initial visit (baseline), and then on days 2, 4 and 7. Initial severity differences did occur between the two groups in certain areas as each participant's severity and rash distribution was different, making matching difficult. It was evident that five of the 10 areas were most commonly affected in all participants - both buttocks, the genitals and the inner thighs - and the results for these areas are given below. The number of participants affected in the other five areas was too small for statistical analysis, however it was noted that there was an improvement in DD symptoms in these regions for both groups over the seven days.

\section{Genital region}

Both groups had a statistically-significant reduction in mean percentage of area affected and rash severity of the genital region by day 7 ( $p=<0.001$ ) (Figures 2 and 3 ). The Wilcoxon signed ranks test indicated that the treatment group had a statistically-significant improvement between the initial visit and day 2 for percentage of area affected ( $p=0.001$; effect size $0.53)$ and for rash severity ( $p=0.007$; effect size 0.45$)$ when compared with the control group (percentage of area affected $p=0.201$, effect size 0.21 ; rash severity $p=0.0336$, effect size 0.16$)$. The control group only showed a statisticallysignificant improvement toward the end of the week. Intergroup analysis, however, revealed no statistically-significant

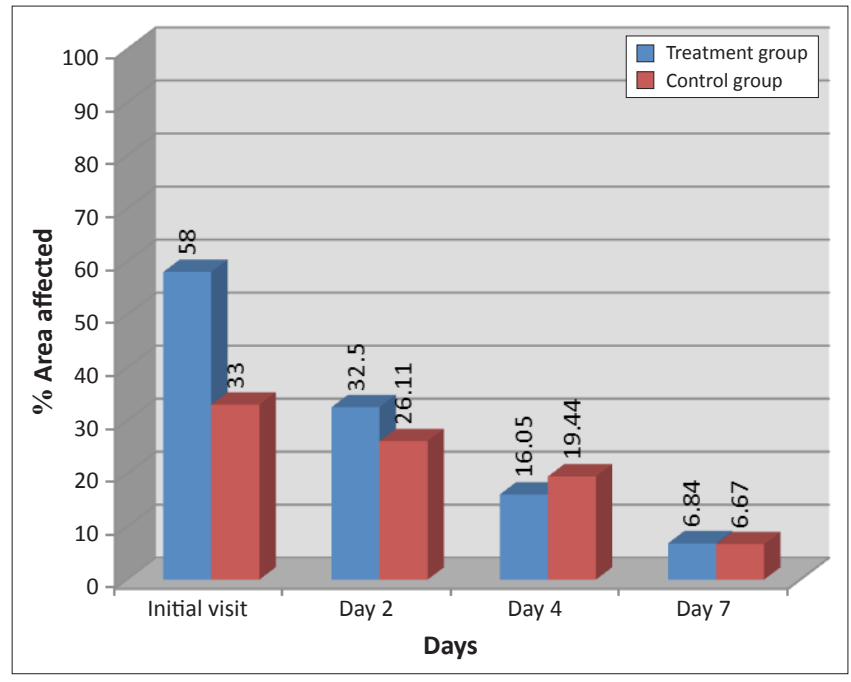

Source: Data collected during study

FIGURE 2: Genital region: Mean percentage area affected according to the Modified Lund and Browder Chart.

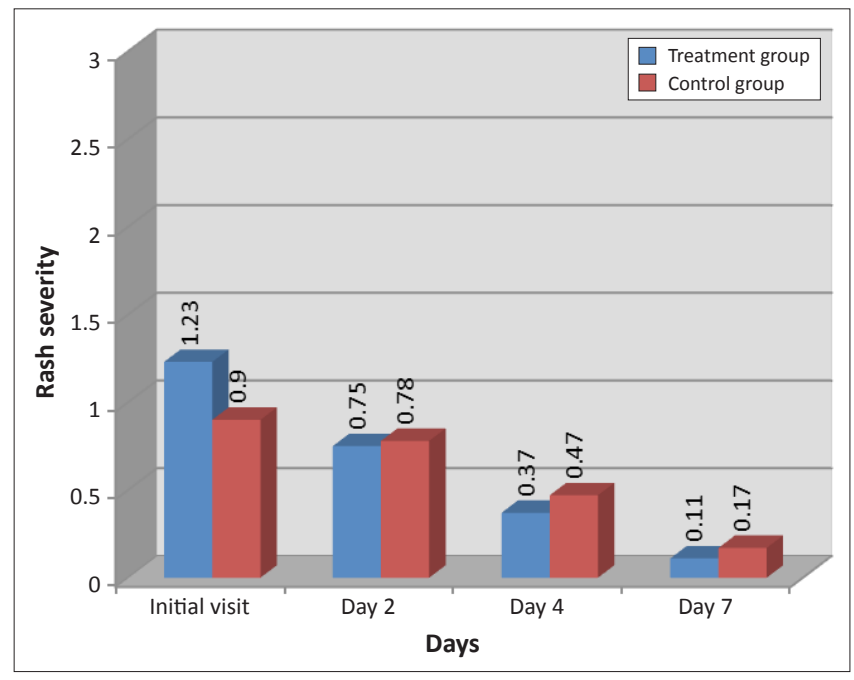

Source: Data collected during study

FIGURE 3: Genital region: Mean rash severity according to the 4-Point Grading Scale.

differences between the two groups for percentage of area affected $(p=0.950)$ or for rash severity $(p=0.593)$ by day 7 , indicating that the treatment group did not outperform the control group.

\section{Right inner thigh}

Both groups had a statistically-significant reduction in mean percentage of area affected and rash severity of the right inner thigh region by day 7 ( $p=<0.001$ ) (Figures 4 and 5). The treatment group showed the greatest reduction of percentage area affected $(94.08 \%)$ as compared with the control group $(46.12 \%)$. The Wilcoxon signed ranks test indicated that the treatment group had a statistically-significant improvement between the initial visit and day 4 for percentage of area affected ( $p=0.002$; effect size 0.51), and between the initial visit and day 2 for rash severity ( $p=0.007$; effect size 0.45$)$, compared with the control group (percentage of area affected $p=0.034$, effect size 0.35 ; rash severity $p=0.809$, effect size 


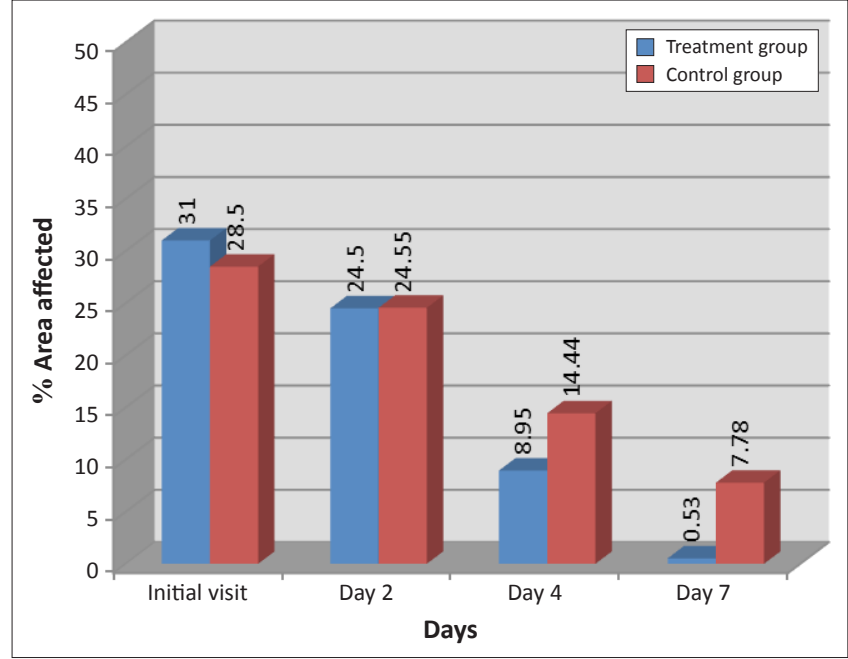

Source: Data collected during study

FIGURE 4: Right inner thigh region: Mean percentage area affected according to the Modified Lund and Browder Chart.

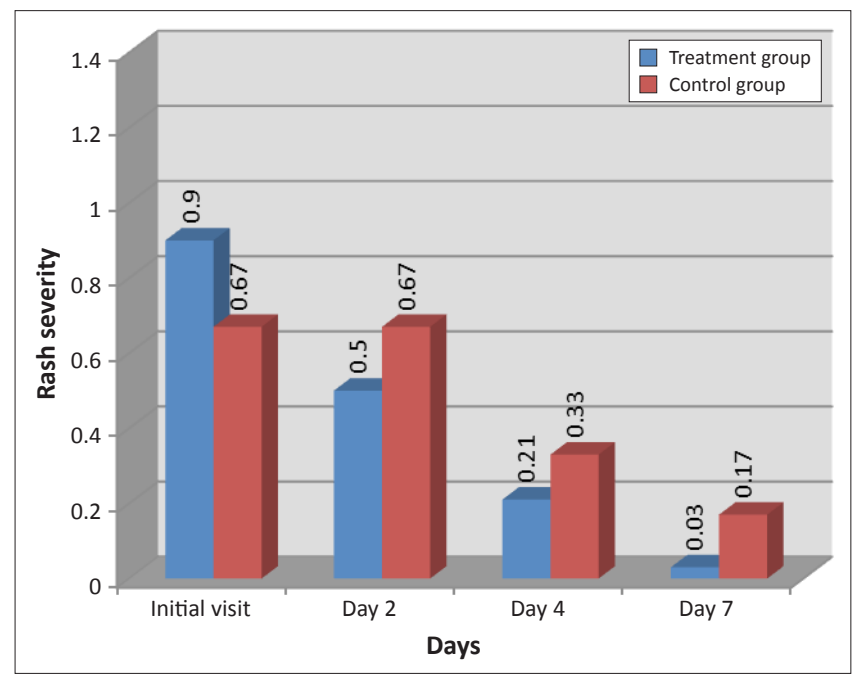

Source: Data collected during study

FIGURE 5: Right inner thigh region: Mean rash severity according to the 4-Point Grading Scale.

0.04). Inter-group analysis, however, indicated no statisticallysignificant differences between the two groups for either the percentage of area affected $(p=0.113)$ or the rash severity ( $p=0.125$ ) by day 7, indicating that the treatment group did not outperform the control group.

\section{Left inner thigh}

The mean percentage of area affected in the left inner thigh region (Figure 6) was initially slightly worse in the control group. Both groups showed a statistically-significant reduction in percentage area affected by day $7(p=<0.001)$, however the treatment group showed a faster reduction (73.69\% reduction by day 4$)$, compared with the control group (27.43\%). The mean rash severity of the left inner thigh region of both groups (Figure 7) improved over the seven days (treatment group $p=<0.001$; control group $p=0.001$ ). Further analysis revealed that the treatment group had a statistically-significant change between the initial visit and day $4(p=0.002)$, and the control group between day 2 and

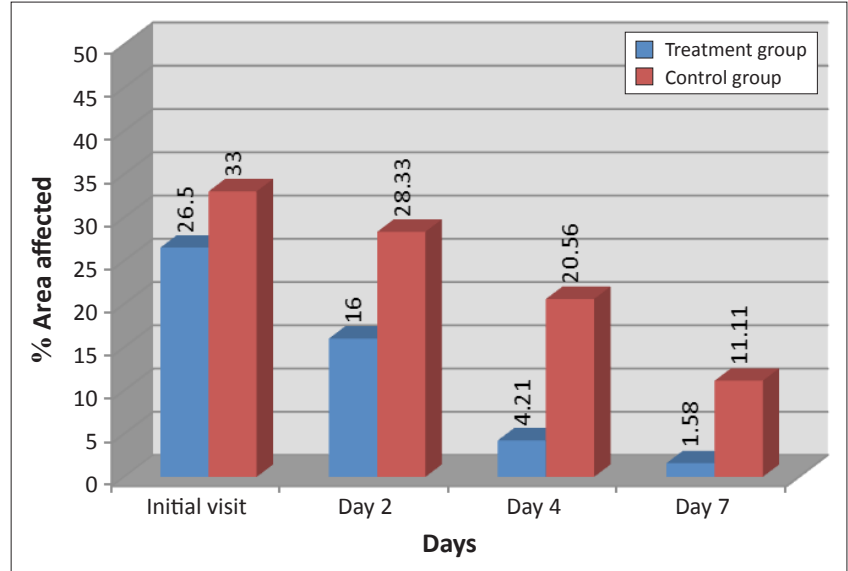

Source: Data collected during study

FIGURE 6: Left inner thigh region: Mean percentage area affected according to the Modified Lund and Browder Chart.

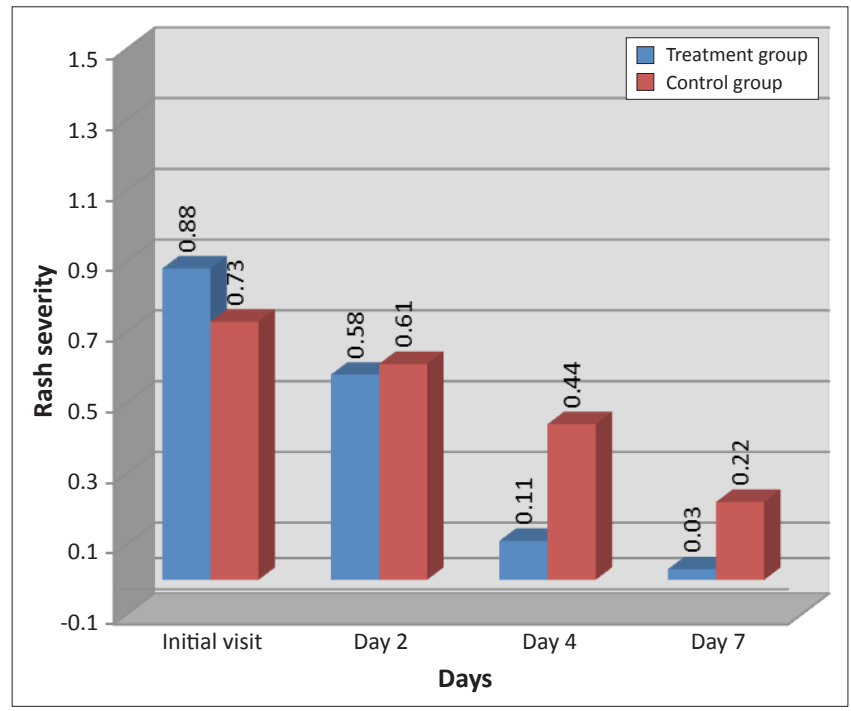

Source: Data collected during study

FIGURE 7: Left inner thigh region: Mean rash severity according to the 4-Point Grading Scale.

day $7(p=<0.006)$. The greatest effect size difference was seen between the initial visit and day 2 (treatment $=0.42$; control $=0.05)$. Inter-group analysis revealed statisticallysignificant differences on days $4(p=0.003)$ and $7(p=0.033)$ for percentage of area affected, and on days $4(p=0.004)$ and $7(p=0.029)$ for rash severity, indicating that the treatment group outperformed the control group.

\section{Right buttock}

Both groups had a statistically-significant reduction in mean percentage of area affected and rash severity of the right buttock region by day 7 ( $p=<0.001$ ) (Figures 8 and 9). The Wilcoxon signed ranks test indicated that the treatment group had a statistically-significant improvement between the initial visit and day 2 for percentage of area affected $(p=0.009$; effect size 0.43), compared with the control group ( $p=0.363$; effect size 0.15); and between the initial visit and day 4 for rash severity ( $p=0.002$; effect size 0.51$)$, compared with the control group ( $p=0.529$; effect size 0.1$)$. Inter-group analysis revealed statistically-significant differences on day 4 


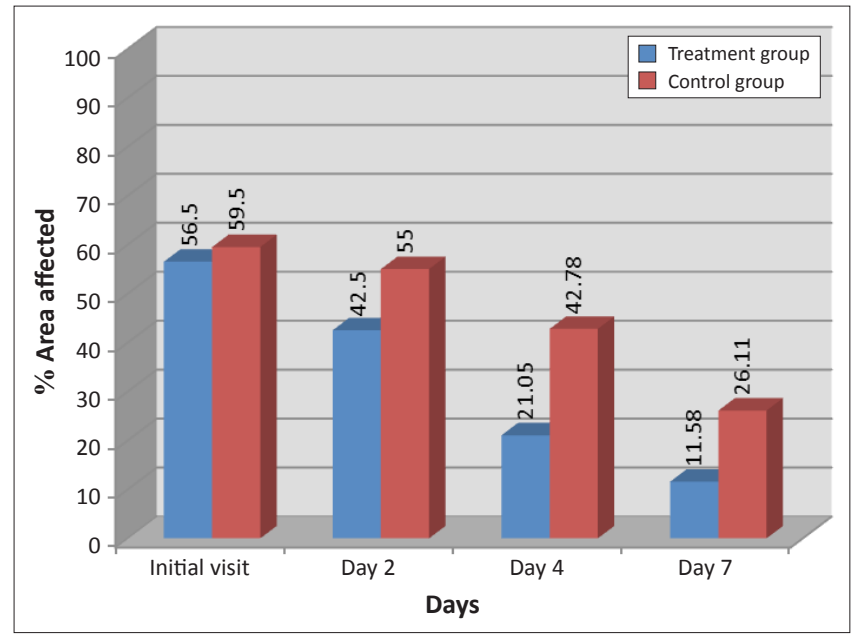

Source: Data collected during study

FIGURE 8: Right buttock region: Mean percentage area affected according to the Modified Lund and Browder Chart.

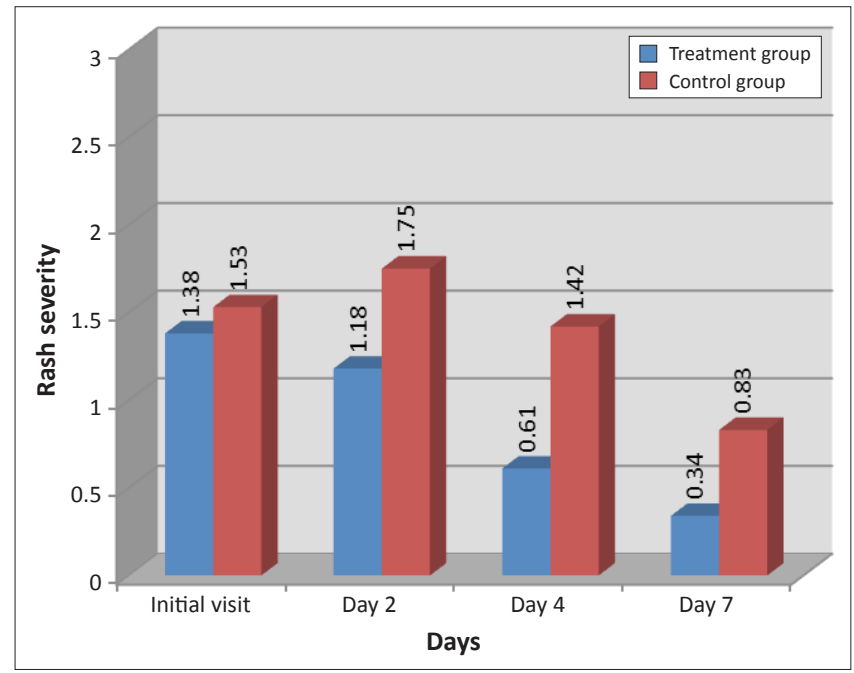

Source: Data collected during study

FIGURE 9: Right buttock region: Mean rash severity according to the 4-Point Grading Scale.

( $p=0.010)$ and day $7(p=0.024)$ for percentage of area affected, and on days $2(p=0.048), 4(p=0.005)$ and $7(p=0.019)$ for rash severity, indicating that the treatment group outperformed the control group.

\section{Left buttock}

Both groups had a statistically-significant reduction in mean percentage of area affected and rash severity by day 7 $(p=<0.001)$ (Figures 10 and 11). The Wilcoxon signed ranks test indicated that the treatment group had a statisticallysignificant improvement between the initial visit and day 4 for both percentage of area affected ( $p=0.001$; effect size 0.49 ) and for rash severity ( $p=0.005$; effect size 0.46 ), compared with the control group (percentage of area affected $p=0.063$, effect size 0.38 ; rash severity $p=0.467$, effect size 0.12 ). Intergroup analysis revealed statistically-significant differences on days4 $(p=0.006)$ and $7(p=0.010)$ for percentage of area affected, and on days $2(p=0.067), 4(p=0.002)$ and 7 $(p=0.010)$ for rash severity, indicating that the treatment group outperformed the control group.

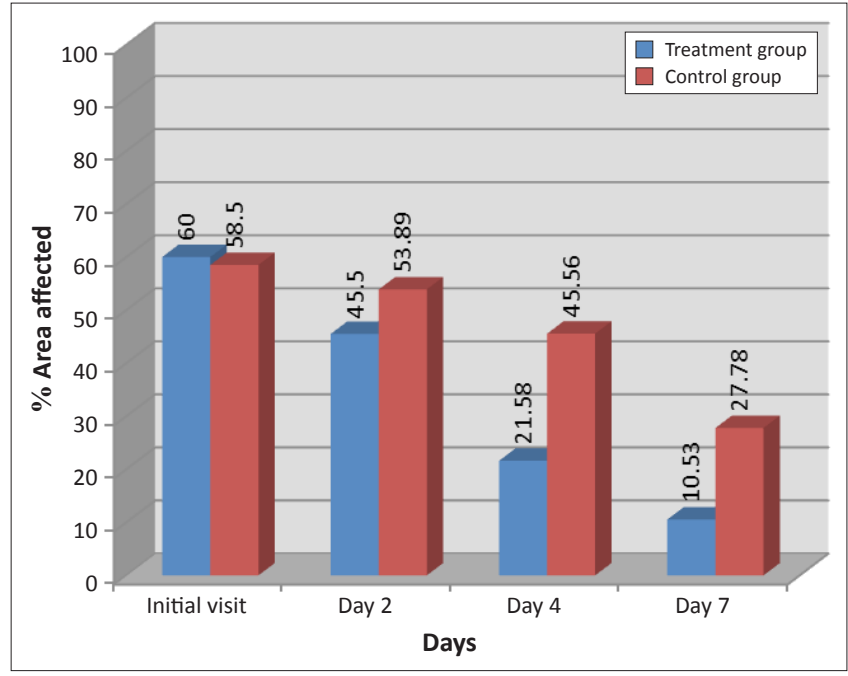

Source: Data collected during study

FIGURE 10: Left buttock region: Mean percentage area affected according to the Modified Lund and Browder Chart.

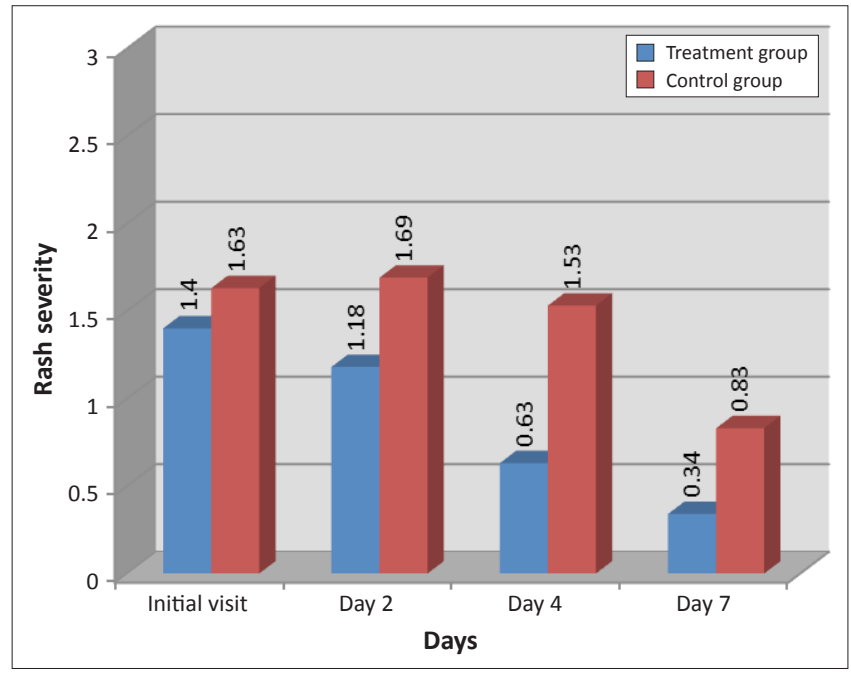

Source: Data collected during study

FIGURE 11: Left buttock region: Mean rash severity according to the 4-Point Grading Scale.

It was noted that each participant in the control group received on average more frequent daily applications of the cream (5.18) than the participants within the treatment group (4.63).

\section{Discussion}

DD is a common problem and is of concern for both parents and healthcare providers. The symptoms of DD are distressing for the infant, and require an appropriate and rapidly-effective treatment plan (Friedlander et al. 2009). In this study, homeopathically-medicated milking cream was compared with unmedicated milking cream to evaluate its efficacy in alleviating the symptoms of DD.

\section{Discussion of the ingredients of milking cream}

The individual ingredients of milking cream have shown potential benefits in the treatment of skin conditions. Chlorhexidine is an antiseptic which is particularly effective 
against staphylococcal infections. One double-blind comparative study evaluating the antiseptic efficacy of a topical triclosan and/or chlorhexidine combination in adults with atopic dermatitis, found that it was effective in the control of pathogens and aided in the management of dermatitis (Wohlrab et al. 2007). With regard to Vitamin E, there is evidence to suggest that topical use helps to balance and maintain the skin barrier, making it potentially useful for $\mathrm{DD}$, however further studies are needed to determine its efficacy for this condition (Thiele \& EkanayakeMudiyanselage 2007). Lanolin is an emollient that is obtained from sheep's wool, and comprises of wool alcohols, fatty alcohols and fatty acids. It is a natural emulsifier and is a common ingredient in cosmetics. Whilst lanolin has shown humectant and wound-healing properties, and appears to be safe in healthy individuals, it has also been implicated as a possible allergen in atopic dermatitis sufferers. In a retrospective analysis on the incidence of lanolin allergy, however, over a 15-year period, involving 24449 patients, the mean annual rate of sensitivity to wool alcohol in patients with or without atopic dermatitis was relatively low $(1.7 \%)$ (Stone 2000; Visscher 2009; Wakelin et al. 2001). The efficacy of milking cream for DD has to date not been evaluated; it was hypothesised that the combined effects of these ingredients would be beneficial to DD sufferers. In this study, milking cream served as the control cream as well as the base for the homeopathic complex.

\section{Calendula officinalis}

The homeopathic remedies included in this complex cream have shown potential benefits in healing skin conditions. Calendula officinalis is made from marigold flowers, and has anti-inflammatory, antiviral, antibacterial and antifungal properties (Efstratiou et al. 2012; Muley et al. 2009; Preethi, Kuttan \& Kuttan 2009; Ukiya et al. 2006). Chandran and Kutton (2008) showed that the topical use of C. officinalis had a significant effect in improving wound healing in rats with thermal burns. They postulated that the anti-oxidant activity of Calendula spp. might have played a role in this phenomenon. One in vitro study supports these findings and has shown that $C$. officinalis extracts appear to stimulate the proliferation and migration of fibroblasts. Fibroblasts play a crucial role in wound healing and this study showed that, even at low concentrations $(10 \mu \mathrm{g} / \mathrm{mL})$, C. officinalis enhanced cell numbers by between $64.35 \%$ and $70.53 \%$, thus possibly leading to a more rapid recovery time in clinical situations (Fronza et al. 2009). A study done by Gazim et al. (2008) indicated that the use of C. officinalis is beneficial for the treatment of Candida albicans and various bacteria. As secondary infections are common in infants with DD and can have a large impact on the severity of the condition, the use of C. officinalis is therefore well indicated. Apart from its healing properties, Calendula may also help prevent dermatitis, and in one study, the preliminary data supports the efficacy of the topical use of $C$. officinalis in the prevention of radiotherapyinduced dermatitis (Kassab et al. 2009). Specifically with regards to DD, one randomised comparative trial compared the therapeutic effects of $C$. officinalis ointment and Aloe vera gel on 66 infants with DD. The treatments were applied topically three times daily for 10 days and favourable effects were noted in both groups, however the Calendula group had a higher therapeutic effect than the Aloe group, and no adverse effects were noted (Panahi et al. 2012).

\section{Atropa belladonna and Sulphuricum acidum}

Atropa belladonna is a homeopathic remedy made from the deadly nightshade plant and has traditionally been used for its wound healing properties (Gál et al. 2012). Toporcer et al. (2006) conducted a study on the use of A. belladonna water extract on skin wounds in rats, which showed a positive effect of increasing the rate of aseptic surgical wound healing. In 2009, Gál et al. confirmed that this extract promoted healing of cutaneous wounds through its anti-inflammatory properties and by increasing collagen deposition and tensile strength. A further study showed that A. belladonna modulates wound healing by inducing fibronectin and galectin- 1 rich extracellular matrix formation, as well as by increasing the proliferation of keratinocytes. These effects, however, are dependent on the concentration of the extract, with higher dilutions seeming to have more therapeutic effects (Gál et al. 2012).

Sulphuricum acidum (made from sulphuric acid) is clinically indicated for skin conditions characterised by excoriation, erythema, itching and pain, and is one of the main remedies indicated for streptococcal, staphylococcal and Candida albicans infections (Gupta \& Manchanda 2005:85; Vermeulen 2001:930-933).

No previous studies have been conducted on the efficacy of the topical application of Atropa belladonna or Sulphuricum acidum on infants with DD. Both remedies were used in a highly diluted form ( $6 \mathrm{cH}$ potency) in this study. Homeopaths potentise substances in order to reduce their harmful, toxic effects, as well as potentiate their therapeutic properties.

\section{Outline of the results}

In this study, both the treatment and control groups showed significant improvements on the percentage of all areas affected and on rash severity between consecutive visits, as well as over the entire research study period. These findings indicate that both creams were effective in relieving the symptoms and signs of DD. Inter-group analysis revealed that statistically-significant differences between the groups were noted on the right and left buttock, as well as the left inner thigh, for both rash severity and percentage of area affected, indicating that the treatment cream outperformed the control cream.

Although improvement of DD was observed in both groups, the treatment group appeared to have had a higher therapeutic effect, with a faster resolution of symptoms compared with the control, in these body regions. A possible explanation for why there was no statistically-significant difference in the genital region may be due to poor matching in this region. Matching according to severity of the symptoms proved difficult due to the large number of regions assessed in this study. 
In general, the control group received $10.62 \%$ more frequent applications than the treatment group, indicating that the treatment group possibly appeared to need less cream application due to the faster decrease of the DD symptoms and signs. Whilst the potential exists for hypersensitive individuals to develop an allergy to any of the ingredients in the creams, no adverse effects were noted by any participants' parents or guardians in either group.

\section{Practical implications}

It can be concluded that the homeopathic remedies added to the milking cream showed a greater and more rapid reduction in DD symptoms in comparison to the control group, possibly due to the anti-inflammatory and anti-oxidant effects which they possess. Furthermore, the antimicrobial activities of the remedies may have helped prevent and treat secondary bacterial and fungal infections. It is also believed that the ability of these remedies to stimulate collagen production resulted in stronger barrier function as well as the prevention of trans-epidermal water loss (TEWL).

\section{Limitations of the study}

Due to the small sample size, the number of participants affected in certain areas such as the abdomen and outer thighs was too small to analyse statistically. A larger sample group would have possibly yielded more statistically-viable results. Matching of the groups was difficult due to the large number of areas being assessed, and the matching criteria. The milking cream was medicated with homeopathic remedies made in alcohol, according to standard homeopharmaceutic procedures. Alcohol, according to Chauhan, Raut and Karuppayil (2011), assists in the treatment of Candida albicans, a common secondary infection in DD cases, thus participants in the treatment group may have received a slightly additional benefit from the alcohol in the cream, although the alcohol content of the cream was minimal. Alcohol also has the potential to cause irritation to the skin and burning and discomfort when applied. No adverse effects were noted in this study.

\section{Recommendations}

It is recommended that future studies on similar treatment protocols use larger sample groups which would produce more representative results, and should concentrate on the five most commonly-affected sites of the body. Future studies might consider preparing the remedies in an aqueous base rather than an alcohol base, which might limit any possible sensitivity or burning of compromised skin. Other known barrier creams for DD can be compared to the combination used in this study. Future studies might also look at the effect this homeopathic combination has on micro-organisms such as Candida albicans, which will provide extra objective data. Other known homeopathic remedies that match the morphological presentation of DD can be added to the complex for further evaluation.

\section{Conclusion}

The results showed that both the homeopathic complex cream as well as the unmedicated milking cream by itself had an ameliorating effect on DD in infants and could serve as a safe and effective alternative treatment for this condition. Evidence also showed that the treatment group outperformed the control group in certain affected areas, and seemed to have a more rapid resolution of symptoms. Further investigation is warranted.

\section{Acknowledgements}

This work was financed and supported by the University of Johannesburg. The contents of this work are solely the responsibility of the authors and do not represent the official views of UJ. Acknowledgements are also made to Dr J.L. Schultz M.TechHom. (TWR) for her contribution to this research study.

\section{Competing interests}

The authors declare that they have no financial or personal relationship(s) which may have inappropriately influenced them in writing this article.

\section{Authors' contributions}

M.S. (University of Johannesburg) conducted the study for the completion of his Master's degree in Homeopathy, J.P. (University of Johannesburg) supervised the research, and both wrote the manuscript.

\section{References}

Barkin, M.B. \& Rosen, P., 2003, Emergency pediatrics: A guide to ambulatory care, Mosby, Pennsylvania.

Chandran, P.K. \& Kutton, R., 2008,'Effects of Calendula officinalis flower extract on acute phase proteins, antioxidant defence mechanism and granuloma formation during thermal burns', Journal of Clinical Biochemistry and Nutrition 43(2), 58-64. http://dx.doi.org/10.3164/jcbn.2008043, PMCid:PMC2533690

Chauhan, N.M., Raut, J.S. \& Karuppayil, S.M., 2011, 'A morphogenetic regulatory role for ethyl alcohol in Candida albicans', Mycoses 54(6), 697-703. PMid:21605190 http://dx.doi.org/10.1111/j.1439-0507.2010.02002.x

Concannon, P., Gisoldi, E., Phillips, S. \& Grossman, R., 2001, 'Diaper dermatitis: A therapeutic dilemma. Results of a double-blind placebo controlled trial of Miconazole Nitrate 0.25\%', Pediatric Dermatology 18(2), 149-155. PMid:11358560 http://dx.doi.org/10.1046/j.1525-1470.2001.018002149.x

De Wet, P.M., Rode, H., Van Dyk, A. \& Millar, A.J.W., 1999,'Perianal candidosis - a comparative study with mupirocin and nystatin', International Journal of Dermatology 38(8), 618-622. http://dx.doi.org/10.1046/j.1365-4362.1999.00757.x, PMid:10487455

Efstratiou, E., Hussain, A.I., Nigam, P.S., Moore, J.E., Ayub, M.A. \& Rao, J.R., 2012 'Antimicrobial activity of Calendula officinalis petal extracts against fungi, as well as Gram-negative and Gram-positive clinical pathogens', Complementary Therapies in Clinical Practice 18(3), 173-176. http://dx.doi.org/10.1016/j.ctcp.2012.02.003, PMid:22789794

Fernandes, J.D., Machadoll, M.C.R. \& De Oliveirall, Z.N.P., 2009, 'Clinical presentation and treatment of diaper dermatitis - Part II', Anais Brasileiros de Dermatologia 84(1), 47-54. http://dx.doi.org/10.1590/S0365-05962009000100007

Fölster-Holst, R., Buchner, M. \& Proksch, E., 2011, 'Diaper dermatitis', Hautarzt 62(9), 699-708. PMid:21882101

Friedlander, S.F., Eichenfield, L.F., Leyden, J., Shu, J. \& Spellman, M.C., 2009, ‘Diaper dermatitis: appropriate evaluation and optimal management strategies', Contemporary Pediatrics Suppl., 2-14.

Fronza, M., Heinzmann, B., Hamburger, M., Laufer, S. \& Merfort, I., 2009, 'Determination of the wound healing effect of Calendula extracts using the scratch assay with 3T3 fibroblasts', Journal of Ethnopharmacology, 126(3), 463-467. http://dx.doi.org/ 10.1016/j.jep.2009.09.014

Gál, P., Toporcer, T., Grendel, T., Vidová, Z., Smetana, K. Jr., Dvoránková, B., Gál, T., Mozes, S., Lenhardt, L., Longauer, F., Sabol, M., Sabo, J. \& Backor, M., 2009, 'Effect of Atropa belladonna L. on skin wound healing: biomechanical and histological study in rats and in vitro study in keratinocytes, 313 fibroblasts, and human umbilical vein Wound Repair and Regeneration $17(3), 378-386$. http://dx.dol. org/10.1111/j.1524-475X.2009.00475.x 
Gál, P., Vasilenko, T., Kováč, I., Kostelníková, M., Jakubčo, J., Szabo, P., Dvořánková, B. Sabol, F., Gabius, H.J. \& Smetana, K. Jr., 2012, 'Atropa belladonna L. water extract: modulator of extracellular matrix formation in vitro and in vivo', Physiological Research 61(3), 241-250. PMid:22480427

Gazim, Z.C., Rezende, C.M., Fraga, S.R., Svidzinski, T.E. \& Cortez, D.G., 2008, 'Antifungal activity of the essential oil from Calendula officinalis growing in Brazil', Brazilian Journal of Microbiology 39(1), 61-63. http://dx.doi.org/10.1590/S1517-83822008000100015

Gupta, R. \& Manchanda, R.K., 2005, Textbook of dermatology for homoeopaths, B. Jain Publishers, New Delhi.

Kassab, S., Cummings, M., Berkovitz, S., van Haselen, R. \& Fisher, P., 2009, 'Homeopathic medicines for adverse effects of cancer treatments', Cochrane Database Systematic Review, 15(2), CD004845.

Kayne, S.B., 1997, Complete therapies of pharmacists, Pharmaceutical Press, London.

Muley, B.P., Khadabadi, S.S. \& Banarase, N.B., 2009, 'Phytochemical constituents and pharmacological activities of Calendula officinalis Linn (Asteraceae): A review', Tropical Journal of Pharmaceutical Research 8(5), 455-465. http://dx.doi.org/ 10.4314/tjpr.v8i5.48090

National Registry of Emergency Medical Technicians, n.d., 'EMT Course Study Helper', viewed 29 October 2009, from http://www.heretek.net/ems/charts.html

Palestine, R.F., Ehrlich, A., Lee, J.I., Rubin, I.K., Shah, G.M., Yu, T.C., Zahir, K.S., Whitman, J.I. \& Gawler, A., n.d., 'Contact Dermatitis Evaluation Form', viewed 23 Octobe 2009, from http://www.dermskin.com/.../Contact-Dermatitis-Evaluation-Form.pdf

Panahi, Y., Sharif, M.R., Sharif, A., Beiraghadar, F., Zahiri, Z., Amirchoopani, G., Marzony, E.T. \& Sahebkar, A., 2012, 'A randomized comparative trial on the therapeutic efficacy of topical aloe vera and Calendula officinalis on diaper dermatitis in children', Th Scientific World Journal, 2012, 1-5. http://dx.doi.org/10.1100/2012/810234 PMCid:PMC3346674

Preethi, K.C., Kuttan, G. \& Kuttan, R., 2009, 'Anti-inflammatory activity of flower extract of Calendula officinalis Linn. and its possible mechanism of action', Indian extract of Calendula officinalis Linn. and its possible mechanism of
Journal of Experimental Biology, 47(2), 113-120. PMid:19374166

Railan, D., Wilson, J.K., Feldman, S.R. \& Fleischer, A.B., 2002, 'Pediatricians who prescribe clotrimazole-betamethasone diproprionate (Lotrisone) often utilize it in inappropriate settings regardless of their knowledge of the drug's potency', Dermatology Online Journal, 8(2), 3. PMid:12546758

Snyman, J.R. (ed.), 2007, Monthly Index of Medical Specialities, Magazine Publishers, South Africa.
Stone, L., 2000, 'Medilan: a hypoallergenic lanolin for emollient therapy', British Journal of Nursing, 9(1), 54-57. PMid:10887849

Thiele, J.J. \& Ekanayake-Mudiyanselage, S., 2007, 'VitaminE in human skin: organspecific physiology and considerations for its use in dermatology', Molecular Aspects Of Medicine, 28(5-6), 646-667. http://dx.doi.org/10.1016/j.mam.2007.06.001

Toporcer, T., Grendel, T., Boris, V., Gal, P., Sabo, J. \& Hudal, R., 2006, 'Mechanical properties of skin wounds after Atropa belladonna application in rats', Journal of Metals, Materials and Minerals, 16(1), 25-29.

Ukiya, M., Akihisa, T., Yasukawa, K., Tokuda, H., Suzuki, T. \& Kimura, Y., 2006, 'Antiinflammatory, anti-tumor-promoting, and cytotoxic activities of constituents of marigold (Calendula officinalis) flowers', Journal of Natural Products, 69(12), 1692-1696. http://dx.doi.org/10.1021/np068016b

Vermeulen, F., 2001, Concordant Materia Medica, Indian Books \& Periodicals Publishers, New Delhi.

Visscher, M.O., 2009, 'Update on the Use of Topical Agents in Neonates', Newborn \& Infant Nursing Reviews 9(1), 31-47. http://dx.doi.org/10.1053/j.nainr.2008.12.010

Visscher, M.O. \& Hoath, S.B., 2006, 'Diaper dermatitis', in A. Chew \& H.I. Maibach (eds.), Irritant Dermatitis, pp. 37-51, Springer, New York. http://dx.doi.org/10.1007/3540-31294-3_5

Vithoulkas, G., 1981, Science of homoeopathy: the classic homeopathic textbook, Thorson's Publishers, London.

Wachtel, T.L., Berry, C.C., Wachtel, E.E. \& Frank, H.A., 2000, 'The inter-rater reliability of estimating the size of burns from various burn area chart drawings', Burns 26(2),157-170. http://dx.doi.org/10.1016/S0305-4179(99)00047-9

Wahrman, J.E. \& Honig, P.J., 2000, 'Clinical features and differential diagnosis', in J. Harper, A. Oranje \& N. Prose (eds.), Textbook of Pediatric Dermatology, Vol.1, Blackwell Science Ltd, London.

Wakelin, S.H., Smith, H., White, I.R., Rycroft, R.J.G. \& Mcfadden, J.P., 2001, 'A retrospective analysis of contact allergy to lanolin', British Journal of Dermatology 145(1), 28-31. $\mathrm{http}: / / \mathrm{dx}$.doi.org/10.1046/j.1365-2133.2001.04277.x, PMid:11453903

Wohlrab, J., Jost, G. \& Abeck, D., 2007, 'Antiseptic efficacy of a low-dosed topical triclosan/chlorhexidine combination therapy in atopic dermatitis', Skin Pharmacology and Physiology 20(2), 71-76. http://dx.doi.org/10.1159/000097653

Wolf, R., Wolf, D., Tüzün, B. \& Tüzün, Y., 2000, 'Diaper dermatitis', Clinics in Dermatology 18(6), 657-660. http://dx.doi.org/10.1016/S0738-081X(00)00157-7 